\title{
Bone Cancer cM1b TNM Finding v8
}

National Cancer Institute

\section{Source}

National Cancer Institute. Bone Cancer CM1b TNM Finding v8. NCI Thesaurus. Code C136568.

Bone cancer with metastasis in the bone or other distant sites. (from AJCC 8th Ed.) 